\title{
The EU in its most serious crisis ever (and that's not the Euro crisis)
}

VB verfassungsblog.de/the-eu-in-its-most-serious-crisis-ever-and-thats-not-the-euro-crisis/

Dimitry Kochenov Do 13 Jun 2013

Do 13 Jun

2013

Following the recent fascinating exchange in the 'pages' of the Verfassungsblog on what to do (or not) with Hungary given the current developments there it seems to be high time to return to the very basic question on the reasons behind the Union in Europe. The question of Europe's raison d'être is as acute as ever now more than half a century into the project and is actively discussed for a good reason (eg de Búrca 2013). Answering this question is crucial - not only because such an answer could allow for a better legitimization - if not justification of the integration project already in existence, but also, since it is likely to shed light on how to resolve some of the outstanding problems which the Member States and the Union are facing. Although Hungary immediately comes to mind, the situation there is merely an illustration of the extent of the vulnerability of the Union in its entirety, caused by a far-reaching systemic problem of the European Union's design and day-to-day functioning that stretches far beyond the enforcement issues. This systemic deficiency was bound to emerge sooner or later, whether in Hungary or elsewhere. Any other country could be in Hungary's place. Given the current level of interdependence between states in the Union, everybody is harmed by such Hungaries significantly.

In what follows, after asking the question, I make three interrelated arguments to come to an uneasy conclusion. Firstly, I argue that the initial idea behind the Union got hijacked by the internal market, the latter intended as a means, not as an end in itself, exposing a justice void at the basis of the Union. Secondly, I argue that unlike states, the Union is not equipped to defend its founding idea (should it be deciphered). Indeed, it is particularly vulnerable in relation to the founding values, since what it was designed to protect and to fight for is, essentially, the acquis, nothing more; Thirdly, I argue that this obscured the very essence of all the integration exercise, especially in the context of the Union's constant growth, where some states came to look at it as a likely guarantor of their adherence to democracy, the rule of law and human rights protection, exacerbating the justice problem. Lastly, I argue that the EU, which is not a justice actor (as it has been hijacked by the market ideology, which cannot meet expectations directed towards it and is toothless in protecting the essential core of what European integration is about - the values of democracy, the rule of law and human rights protection) is facing the most serious crisis in its history. This has to be stated and clearly acknowledged.

Make no mistake: the problems with the EMU are huge, the difficulties related to building the market were grave. Yet the crisis plaguing the Union due to the combination of all the three factors introduced above is something radically different and is seemingly entirely beyond the Union's control, as it deeply undermines the presumption of a democratic Member State based on the Rule of Law on which the whole world of EU integration rests.

\section{Who can answer the "What For?" Question?}

Any state, even while usually taking its own existence for granted, knows what it is for: school books are written to answer this basic question. So should the reasons question arrive, the range of answers will most likely be quite narrow - from 'it has always been like this' to a long story in the vein of Renan's 'l'oubli [et] l'erreur historique' - the given state's founding mythology. Law is then put in place to reflect this mythology and defend it against any possible encroachments: false monarchs and deviant preachers will be decapitated, antirevolutionaries expelled and the unpopular will lose elections.

Crucially, it is not only the law made in accordance with the cherished idea that will be vehemently guarded by the State. This idea as such is necessarily protected, which is why all the checks and balances, judicial review, elections etc. as well as punishments for 'disloyalty' are put in place. Any polity is about a certain vision of justice and its reflection in the law, combined with the protection of this vision at the root.

At the first glance the same situation seems to be reflected in the European Union: democracy, the rule of law, 
human rights protection - all what Article $2 \mathrm{EU}$ preaches, rose to prominence during the first decades of its existence, materializing from a cocktail of national courts' de facto blackmail, basic common sense, and paying respects to the obvious requirements of contemporary life. Yet, the fact that Article 2 is there does not actually remove acuteness from the question about the reasons behind the Union. It is not for nothing that when one thinks about the EU democracy or human rights protection would be the last thing to come to mind, lagging far behind bananas, motorcycle trailers and even the prohibition to deport foreign prostitutes (as long as they are not a burden on a social security system). This is because democracy and the rule of law are not EU's founding ideas, or paraphrasing Joseph Weiler, not in EU's DNA (SJLS 2012) - left seemingly entirely to the Member States. What we have then, what the DNA is about, is seemingly the internal market. While its value might be huge, its constitutional significance is less prominent, should constitutionalism be taken seriously.

\section{Means hijacking the ends: The justice void}

The foundational aspirational idea of justice cannot be related to the market only, putting EU's story into perspective. Although market now, regrettably, stands alone, without the mantle of ideals, to refer to Joseph Weiler again (CUP 1999), it is obvious that this has not always been the case, on which fact the majority of the students of integration agree. In fact, the EU was created to bring about peace and better life for all, should we be faithful to the story of its first steps. A fédération européenne, to be brought about via the creation of the internal market - should we believe the Schuman Declaration, stood for something significantly more farreaching than the idea of economic integration as such. Although, the Union's ambition has gradually been scaled down to the market - call it a hijacking of the ends by the means - de facto it started playing, mostly through negative integration, the role of the promoter of liberal and tolerant nationhood, as rightly characterized by Will Kymlicka - promoting a very clear idea of constitutionalism based on proportionality, the glorification of reasons, the idea that the law should make sense as well as basic mutual respect among the Member States (OUP 2008). This came down to frowning upon the ideology of 'thick' national identities, however glorified in some schoolbooks.

The EU thus emerged as a vehicle of negative market-based approach to the 'justice' question, for which it is rightly criticized by e.g. Sascha Somek and Andrew Williams, among numerous others. Clearly, creating a market and questioning the state is not sufficient as a basis for a mature constitutional system, potentially creating a justice void at the supranational level.

To sum up: given that the initial promise of integration is substituted by the internal market and assuming that market is not about justice - even less so when justice is about the idea of justification in the market context (i.e. against the standard of the market) - the EU simply cannot answer the raison d'être question on its own, without external hints. More importantly still, it does not have the procedures to come up with the answers - or grandeur and vision not to need any procedures. We are thus facing a justice void undermining the Union's justification and successful functioning (to be analyzed in detail in de Búrca /Kochenov /Williams (eds.) Europe's Justice Deficit? Hart 2014). All what Article 2 EU mentions is about the prerequisites of the day-to-day operation of such a void, not about giving any answers.

\section{EU's structural inability to defend its founding values}

This could be one of the logical explanations why Article $7 \mathrm{EU}$, designed to pressure the Member States viewed as departing from the values on which the Union is founded contains a procedure, which is purely political. In the absence of any Union-level answers to the justice question - and given its limited competences, let alone absent procedures to come up with the answers that would be broadly legitimate while respecting the division of competences between the EU and the Member States - only the Herren der Verträge emerge as the sole source of authority to decide on such issues. Wojciech Sadurski explained quite clearly why Article $7 \mathrm{EU}$ is not a panacea equally in practical terms (CJEL 2010). In dealing with Article 2 - approached legalistically - the EU seems to be in need external input.

Moving beyond Article $7 \mathrm{EU}$, ordinary enforcement mechanisms designed to ensure that EU law works in the Member States are always at our disposal. Yet, the clear difference between the enforcement of the law and the 
enforcement of values is omnipresent in this context. The fact seems to be that the EU does not only suffer from its inability to answer the justice question, thus supplying a legitimate answer concerning what it stands for beyond the market - or a procedure to come up with such an answer by itself - but also any ability to enforce the values as mentioned in Article $2 \mathrm{EU}$ in legal terms. Yet, the importance of finding the ways of value-enforcement is crucial and will only be growing in the EU: the current situation is by all means not sustainable.

\section{Growing expectations}

Yet, for many decades the Union has been consistently working against the raison d'être question, denying the very possibility that it would ever arise, presenting itself as solely working within the paradigm of the internal market, which denies serious treatment of the majority of the principles included in Article 2 EU. Only in the context of the preparation of the Eastern enlargement a fascinating situation arose, when the EU de facto ended up seemingly enforcing its foundational values through the pre-accession conditionality policy - to highly questionable results. The Failure of Conditionality in the fields of democracy and the rule of law, which I analyzed elsewhere (Kluwer 2008), now stands overwhelmingly proven by the Hungarian developments. The message that the EU was projecting on the candidate countries was that it will help them improve tout court - the promotion of the basic democratic principles was part of the package. Crucially, no Western European Member State joined the Union on such premise: the EU as founded is a celebration of the democratic nature of all the Member States as functioning democracies based on the rule of law. The enlarging EU, however, was expected to be a careful helper in the areas outside of its reach. The acceding states looked at the EU as a possible guarantor of future democratic stability, to ensure that Hungary never happens. This radical difference in approaches has important implications for the whole EU integration project. Sadurski has brilliantly described this cleavage, covering the Council of Europe too in a recent monograph (OUP 2012).

\section{The biggest crisis in Union's history}

All the problems described, the hijacking of the grand idea of European unity by the market ideology, the EU's inability to answer the raison d'être question as well as the structural justice void, coupled with the Member States' expectation of action led to the biggest crisis in EU history since its creation. Indeed, the real systemic crisis is in the current Hungarian situation, not the state of the EMU, failed referenda, or the blockages by the Member States in the past, like the empty chair policy. All the EMU and empty chair issues can be solved by the EU in the context of the familiar legal field.

The Hungarian situation is markedly different: although the values of Article $2 \mathrm{EU}$ are of essential legal value and importance, the Union is powerless what concerns their enforcement and, more importantly, also content. In fact, talking about enforcing them seriously amounts to nothing else but conceding that the presumption that all the Member States form a level playing field in terms of rule of law etc. does not always hold - something the ECt.HR has already clearly hinted at in M.S.S. v. Belgium and Greece. Acknowledging this alongside EU's obvious powerlessness as far as values are concerned is a potentially explosive combination in the Union built on Member State equality and the principle of mutual recognition. We are not dealing with a Member State revolting, for one reason or another, against a binding norm of European law. At the level of values we are dealing with a principally different Member State, with the Belarusianisation of the EU from the inside. Once the principles of Article $2 \mathrm{EU}$ are not observed, the essential presumptions behind the core of the Union do not hold any more, undermining the very essence of the integration exercise. Dealing with the values emergency and the justice void should become the most important and the most immediate task of the Union and the Member States combined.

LICENSED UNDER CC BY NC ND

SUGGESTED CITATION Kochenov, Dimitry: The EU in its most serious crisis ever (and that's not the Euro crisis), VerfBlog, 2013/6/13, http://verfassungsblog.de/the-eu-in-its-most-serious-crisis-ever-and-thats-not-theeuro-crisis/. 